\title{
Similar impacts of fishing and environmental stress on calcifying organisms in Indian Ocean coral reefs
}

\author{
Timothy R. McClanahan ${ }^{1, *}$, Nyawira A. Muthiga ${ }^{1,2}$ \\ ${ }^{1}$ Wildlife Conservation Society, Marine Programs, 2300 Southern Boulevard, Bronx, NY, 10460 \\ ${ }^{2}$ Wildlife Conservation Society, Marine Programs, POB 99470, Kenya, 80107
}

\begin{abstract}
Calcification and reef growth processes dominated by corals and calcifying algae are threatened by climate and fishing disturbances. Twenty-seven environmental, habitat, and species interaction variables were tested for their influence on coral and calcifier cover in 201 western Indian Ocean coral reefs distributed across $\sim 20^{\circ}$ of latitude and longitude and up to $20 \mathrm{~m}$ deep. These variables predicted more of the total between-site variance of calcifying organism cover $(\sim 50 \%)$ than coral cover ( 20\%). Satellite-derived environmental variables of temperature, light, and water quality predicted more of the coral and calcifier cover than feeding interactions when groups of related variables were analyzed separately. Nevertheless, when simultaneously evaluating all variables, the environmental variables better predicted coral cover, but proxies of feeding interactions better predicted calcifier cover. Coral and calcifier cover were most consistently negatively influenced by sea surface temperature distributions (right skewness), but the orangelined triggerfish Balistapus undulatus consistently had a strong positive association with coral and calcifier cover. Herbivorous fish and Diadematidae sea urchins were not positively associated with coral and calcifier cover. A primary prey of $B$. undulatus, the rock-boring sea urchin Echinometra mathaei, had a strong negative association with coral cover and particularly calcifier cover. Island reefs had higher calcifier abundance than fringing reefs, which probably results from high Acropora and $B$. undulatus but low $E$. mathaei abundance. When comparing all variables and models, these taxonomic associations had more influence than environmental stress variables on calcifiers. Given the important predatory role of $B$. undulatus in controlling $E$. mathaei populations, fishing restrictions on this species could help attenuate calcification losses predicted by climate change.
\end{abstract}

KEY WORDS: Benthic cover - Calcium carbonate $\cdot$ Ecosystem-based management $\cdot$ Climate change $\cdot$ Predation $\cdot$ Resilience

\section{INTRODUCTION}

Calcifying organisms, calcification processes, and reef growth are under threat by multiple forces, including the direct impacts of poor water quality, climate and thermal anomalies, and ocean acidification, as well as the indirect forces of trophic cascades - often catalyzed by fishing (Carreiro-Silva \& McClanahan 2012, Johnson \& Carpenter 2012, Andersson \& Gledhill 2013, Kroeker et al. 2013). These forces are likely to combine and undermine the process of calci-

${ }^{*}$ Corresponding author: tmcclanahan@wcs.org fication and reef growth with the potential to influence reef fisheries and the capacity of reefs to grow and respond to rising sea levels (Wild et al. 2011). Geographic factors are expected to influence the exposures to these forces and interact with fisheries intensity and management to influence local responses (Ateweberhan et al. 2011, Selig et al. 2012). Given the contemporary and projected threats to these organisms and ecological processes, it behooves coral reef investigators to more fully understand the factors associated with and potentially influencing calcifiers.

() The authors 2016. Open Access under Creative Commons by Attribution Licence. Use, distribution and reproduction are unrestricted. Authors and original publication must be credited. 
Benthic organisms in coral reefs are primarily composed of taxa that have made evolutionary, energetic, and functional tradeoffs between organic and inorganic carbon production (Vermeij 1987). The main functional groups contributing to organic production are primarily small turf and larger erect non-calcifying algae and seagrass (McClanahan et al. 2002). Calcifying organisms are primarily composed of hard corals and red coralline and green calcareous algae. All these organisms contribute to primary production, but calcifiers also contribute to reef growth and use the net energy from organic production to support calcification (Albright et al. 2013, Koweek et al. 2015, Shaw et al. 2015). While calcification is expected to increase an organism's survival and fitness in coral reefs (Vermeij 1987), life histories and dominance are expected to change with shifting water temperatures, quality and consumer environments (Bell et al. 2013, Sunday et al. 2014). Thus, niches and taxonomic configurations can shift as reef environments change, with consequences for the organic/ inorganic carbon production.

Reef type, geographic locations, oceanographic and physical features, depth, and exposure to physical energy influence species, community composition, and the distribution of calcifiers in coral reefs (McClanahan \& Karnauskas 2011, Gove et al. 2015). Reef consumers, in turn, influence reef growth directly by eroding calcium carbonate skeletons, but also indirectly by influencing competition between calcifying and non-calcifying organisms (Smith et al. 2010, Kennedy et al. 2013, Bronstein \& Loya 2014). For example, some herbivorous consumers, such as surgeonfish, primarily crop algae or clean calcium carbonate surfaces whereas other consumers, including excavating parrotfish and some sea urchin species, consume calcium carbonate skeletons and increase reef bioerosion (Bellwood et al. 2012, Marshell \& Mumby 2012, Qiu et al. 2014). The various controlling roles of herbivore groups - surgeonfish, parrotfish, rabbitfish, and sea urchin species - in reef interactions and processes is of considerable practical interest to reef condition (Burkepile \& Hay 2010, Thibaut \& Connolly 2013, Humphries et al. 2014, Nash et al. 2015, Russ et al. 2015). For example, the proportion of common bioeroding sea urchins (i.e. the Diadematidae versus Echinometridae) may influence reef growth depending on the abundance of their respective populations in different reef environments (McClanahan et al. 1999, Bronstein \& Loya 2014, McClanahan \& Muthiga 2016).

Investigations into the maintenance of calcification and reef structure have often ignored or underesti- mated the role of reef carnivores and subsequent effects on reef ecology and ecosystem services. Yet, there is good evidence that trophic cascades initiated above the herbivore level influence reef structure and processes (O'Leary \& McClanahan 2010, McClanahan \& Muthiga 2016). Macro-invertebrate feeders consume a mixture of calcifying primary producers, such as hard corals, but also preferentially prey on various mobile invertebrate herbivores and bioeroders, including sea urchins (McClanahan 1999, 2000). Consequently, the diversity and complexity of ecological interactions on coral reefs creates the opportunity for evaluating the important and novel roles of carnivores on reef growth. Carnivores are amenable to local fisheries restrictions and appropriate management could potentially moderate climate impacts that are threatening corals and calcifier populations.

The physical environment interacting with the coral holobiont has been shown to influence coral responses to thermal anomalies (McClanahan \& Maina 2003, Golbuu et al. 2007, Howell et al. 2011). Similarly, there are notable variations in the acclimation/adaptation and refuge potential of corals globally, including the Indian Ocean region (Maina et al. 2011, McClanahan et al. 2011a, Chollett \& Mumby 2013). Studies in the Indian Ocean have uncovered the influences of a number of environmental variables and how they interact to create stressful conditions and vice versa (Maina et al. 2008, McClanahan et al. 2015a). For example, background variation in light and temperature influences the acclimation rates and survival of corals disturbed by climate anomalies (McClanahan et al. 2005, Ateweberhan \& McClanahan 2010). Consequently, the persistence of corals and calcifying organisms is expected to reflect the recent history of environmental conditions.

Given the above findings, the roles of environmental thermal stress and competition mediated by consumers are the most likely factors influencing reef calcifiers and calcification processes. This study evaluates the potential roles and influences of the physical environment and trophic cascade ecology on corals and calcium carbonate-forming organisms. We used data from a broad survey of tropical western Indian Ocean coral reefs collected over $\sim 20^{\circ}$ of longitude and latitude and a depth range of $20 \mathrm{~m}$. Factors examined included reef type, coral growth-form dominance, distance from shore, exposure to the open sea, depth, complexity of the bottom, thermal and light intensity and variation, a multivariate stress model (Maina et al. 2011), the abundance of various herbivore and sea urchin predators, and dominant 


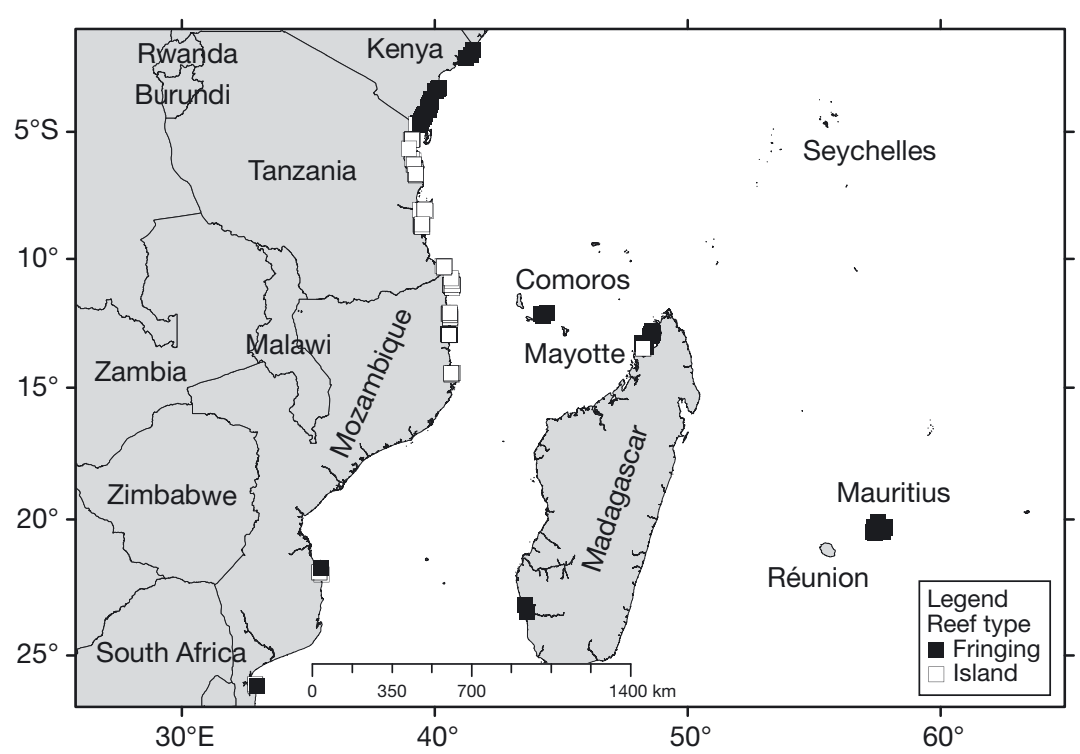

Fig. 1. Location of study sites in the western Indian Ocean region and the distribution of fringing (filled squares) and island (open squares) reef sites

\section{Field methods}

We undertook ecosystem-level studies of coral reefs in the western Indian Ocean reefs (see Supplement at www.int-res.com/articles/suppl/m560 p087_supp.pdf). These ecological field study data were combined with satellite-derived environmental data for a total of 27 variables to be tested for their influences on coral and calcifying cover. These variables included 6 physical factors, 7 herbivore metrics, 5 macro-invertebrate predator metrics, and 9 environmental variables. Measurements at the site level included sampling the benthos, sea urchins, and fish numbers and their biomass (see Supplement). The benthic substrate was sampled using 2 methods, one was the standard $10 \mathrm{~m}$

coral taxa. Using step-wise regression modeling and inclusive (Akaike information criteria, AIC) and exclusive (Bayesian information criteria, BIC) stopping rules, we compared the strength of these factors in predicting coral and calcifying organism cover. This work was undertaken to further test and refine existing hypotheses about environmental versus ecological control of the reef calcification process.

\section{MATERIALS AND METHODS}

\section{Study sites}

Fringing reefs and offshore island reefs are the common reef types and Acropora and massive Porites the dominant coral growth forms in the western Indian Ocean (Fig. 1, Perry et al. 2015, Ateweberhan \& McClanahan 2016). Large fringing reefs are found in southern Kenya, southwest and northeast Madagascar, and surrounding the island of Mauritius. Offshore island reefs are common in the Mozambique Channel from southern Kenya to northern Mozambique and northwest Madagascar. Offshore island reefs are living coral growing on the edges of Pleistocene carbonate islands and submerged banks. Both reef types have an exposed reef edge and sheltered back reef or lagoon where the physical forces of waves are reduced. The reef types, nearest distance to shore (Google maps), as well as the depth and exposure to open sea were recorded for each site. line-intercept transect methodology (McClanahan \& Shafir 1990) and the other was a visual estimate method, which was most frequently used in deeper water where the time required to do the field work was limited (McClanahan et al. 2007a).

Using the line-intercept method, organisms under a loosely draped line were measured and classified into functional groups of hard and soft coral, algae (fleshy, red coralline, i.e. Amphiroa, Jania, Hydrolithon and green calcareous, i.e. Halimeda), seagrass (i.e. Thalassia and Thallasodendron), sponge and sand. Six to 9 replicate transects were done per site and the total lengths of each group were summed and the percent cover was calculated for each substrate category per site. The topographic complexity of the bottom was estimated by the ratio of the bottom contour to straight-line distance using the same $10 \mathrm{~m}$ transect line (McClanahan 1994). The coral structure of the reefs was estimated by calculating the ratio of the dominant branching Acropora to dominant massive Porites. These are the 2 most common branching and massive taxa on these reefs and their cover has influences on the structure and calcification rates on these reefs (Perry et al. 2015).

The visual estimate method classifies cover of hard and soft coral and erect algae into $5 \%$ cover increments in $\sim 20$ replicate and haphazardly placed $2 \mathrm{~m}^{2}$ quadrats per site. This method does not estimate calcifying algae cover and so data collected by this method is only used in tests where coral cover is the response variable. This led to 2 separate analyses, one based on 97 reef site $\times$ time replicates where all 
variables were available, and another based on 168 site $\times$ time replicates with only hard coral. The first analysis had a greater proportion of shallow reefs represented than the second analysis.

Sea urchins were sampled in 9 haphazardly placed $10 \mathrm{~m}^{2}$ circular quadrats where all individuals were counted and recorded to species level. Haphazard samples of $>20$ individuals of each species were collected and their wet weights measured for converting population densities to wet weight biomass. Sea urchin diversity was calculated as a modification of the Simpson's index $\left(D=1-\left(\sum_{s=1}^{n} n i / N_{t}\right)^{2}\right)$, such that 0 represents the lowest and 1 the highest proportional diversity based on individuals (i) per species $(s)$ and the total number of individuals $\left(N_{t}\right)$ in the sample. The predation rates on sea urchins were estimated in selected reefs by tethering 30 sea urchins and counting the numbers remaining after $24 \mathrm{~h}$ (McClanahan \& Muthiga 1989).

Fish biomass and numbers were estimated in $500 \mathrm{~m}^{2}$ belt transects (McClanahan 1994). Fish biomass was based on counts of their numbers, and estimates of body sizes in $10 \mathrm{~cm}$ intervals, with no individuals $<3 \mathrm{~cm}$ counted for 20 families (McClanahan et al. $2015 b)$. Fish were counted in a number of passes of the belt transect where, during the first pass, the individual's family and size were recorded while in subsequent passes, the species were recorded. The wet weight of the fish in each family group was estimated from length-weight relationships for these families combining FishBase reports (www. FishBase. org) and measurements in Kenyan fish landing sites (McClanahan \& Kaunda-Arara 1996).

Environmental exposure data are from the CoRTAD environmental satellite database (www.nodc. noaa.gov/sog/cortad/) and can grossly be categorized into temperature, light, and water quality metrics (chlorophyll and suspended solids). The data used were the satellite time series data collected from 1983 up to the time when the ecological data were collected. We calculated various sea surface temperature (SST) metrics including median, SD, skewness, kurtosis, mean, maximum, and frequency of thermal stress anomalies. Light variables included the median and maximum photosynthetic radiation (PAR) and water quality included the median chl a and suspended solids. We also evaluated a climate exposure and stress model that combined and weighted exposure variables based on their influence on coral bleaching (Maina et al. 2008, 2011). These data were tested for autocorrelation and we selected only one variable when related variables had high correlation (i.e. mean vs maximum temperature and light).

\section{Data analyses}

Line-transect benthic cover data were pooled into calcium carbonate and non-carbonate producer taxonomic groups. The calcium carbonate producer group was the sum of hard coral, red coralline, and green calcareous algae cover. The non-carbonate producer group was the sum of the turf, fleshy algae, sponge, and soft coral cover. Two response variables were used in the analysis, one based on line transects, which measured all calcifying organisms. The second was hard coral cover, which was based on both the line and visual estimate methods. Benthic cover data were logit transformed before analyses (Warton \& Hui 2011). Fish groups were summed to produce a herbivorous fish group and a macroinvertebrate feeder group. Herbivorous fish were calculated as the sum of the acanthurids, scarids, and siganids. Macro-invertebrate feeders were estimated as the sum of triggerfish (after eliminating the planktivorous triggerfish Odonus niger) and wrasses with body lengths $<20 \mathrm{~cm}$ (McClanahan et al. 2015b).

Step-wise regressions were undertaken where groups of related variables were tested for possible significance and then a final comprehensive model included all of the significant factors. To reduce autocorrelation and over-fitting of models, the variables were first tested for autocorrelation and variance inflation factor (VIF) before deciding on the final set of variables to be used in the regression analyses (Mansfield \& Helms 1982). Separate forward stepwise regression analyses were done for coral and calcifying organisms. We also used adequate/liberal $\mathrm{AIC}$ and restrictive/conservative BIC stopping rules to identify the key variables acceptable for inclusion in the final comprehensive model. The use of both stopping rules allows for both inclusive and exclusive decisions when deciding on a variable's possible influence. Because the BIC method penalizes the addition of variables, BIC stopping rules provide the simplest explanation but can under-fit model variables; while AIC stopping rules are more inclusive, can over-fit models, but also have higher predictive ability (Burnham \& Anderson 2002). In some cases, the 2 stopping rules produced the same results, in which case we present only the restrictive BIC results.

Tests for associations were done for physical associations, which include reef type, coral growth form, depth, exposure, distance from shore, and topographic complexity, for herbivore associations, which include various fish and sea urchin abundance variables hypothesized to influence coral-algal relationships, for the macro-invertebrate predator associa- 
tions, and for thermal and environmental stress associations. Finally, the significant variables identified in these specific association analyses were combined and tested in the final comprehensive model. We undertook this modular approach in order to assess possible influences resulting from evaluating related sets of variables that are often hypothesized and tested together without measuring or considering other non-related but potentially influential variables. This type of restricted-variable hypothesis testing is common in ecology and can lack the holism required to evaluate complex systems. This modular and 2-stopping rule approach better distinguishes weak and strong factors and possible statistical acceptance/rejection errors (Type I and II) in the final models. Models were run in JMP version 11.0 (Sall et al. 2001).

\section{RESULTS}

\section{Comparison of reef types}

Island reefs were further from shore than fringing reefs and there were a number of differences in the benthic cover of these reef types (Table 1). Island reefs had more hard coral and sponge cover, a greater ratio of Acropora to massive Porites and more calcifying organism cover than fringing reefs. Fringing reefs had a greater cover of turf algae, seagrass, soft coral, and sand and non-calcifying algae overall. Calcifying organism cover was $31 \%$ higher on island than fringing reefs but there were no differences in topographic complexity and fleshy and coralline algal cover.

There was high variability in total sea urchin biomass with no significant differences between fringing and island reefs for the total biomass and associated diversity (Table 1). There were, however, differences at the species level with higher biomass of Echinometra mathaei, Tripneustes gratilla, Stomopnuestes variolaris, and Toxopneustes pileolus on fringing compared to island reefs. E. mathaei was the most abundant sea urchin species, had high betweenreef variability, and its biomass (mean $\pm \mathrm{SD}, 746 \pm$ $1595 \mathrm{~kg} \mathrm{ha}^{-1}$ ) was 16 times higher on fringing than on patch reefs. Diadema setosum was more abundant on island than on fringing reefs but none of the other species-level Diadematidae comparisons (Diadema savignyi, Echinothrix diadema, and E. calamaris) were statistically different for reef type. The weighted ratio of Echinometridae to Diadematidae was, therefore, high in fringing reefs.
The mean biomass of all herbivorous fish was $\sim 190 \mathrm{~kg} \mathrm{ha}^{-1}$ and $\sim 20 \%$ higher on island than on fringing reefs, attributable to more surgeonfish and parrotfish on island reefs. The main difference in the macro-invertebrate feeding community between reef types was the abundance of orange-striped triggerfish Balistapus undulatus, being twice as abundant on island than on fringing reefs, which led to more macro-invertebrate predator biomass overall. There was, however, only a marginally higher predation index $(\mathrm{p}<0.06)$ on island than fringing reefs where this tethering experiment was undertaken (Table 1).

\section{Coral cover relationships}

All significant variables combined predicted a better fit to calcifier (BIC $\mathrm{r}^{2}=0.47, \mathrm{n}=97$ ) than hard coral cover alone (best $\mathrm{BIC} \mathrm{r}^{2}=0.21$, best $\mathrm{AIC}^{2}=0.27, \mathrm{n}=$ 168) (Tables 2 \& 3). Further, for both hard coral cover and calcifier cover, the satellite-derived environmental stress variables predicted more variance than the ecological variables when the variable associations were analyzed separately. Coral cover was better predicted by environmental variables than calcium carbonate cover, which was better predicted by taxonomic associations. The full or comprehensive models often found possible ecological feeding interactions were significant and more predictive, especially in the final calcium carbonate model.

The step-wise regression analyses with coral cover as the response variable found that AIC and BIC stopping rules were different for physical, herbivore and environmental variables (Table 2). Including all of the physical variables of reef type, depth, distance to shore, exposure, Acropora/massive Porites ratio, and topographic complexity found that Acropora/ massive Porites was the strongest factor, followed by reef type, and distance to shore was only included as significant in the AIC stopping rules. The combined variables predicted 17 and $20 \%$ of the coral cover variance by BIC and AIC stopping rules, respectively (Table 2, Fig. 2). Among the herbivores, coral cover declined with the biomass of $E$. mathaei by both stopping rules. E. mathaei and the Acanthuridae explained 8 to $11 \%$ of the BIC and AIC variance, respectively. Among the carnivores, coral cover was significantly positively associated with the triggerfish $B$. undulatus, and negatively with the Coris wrasses, and $10 \%$ of the variance was explained.

The coral cover environmental associations model included 3 significant variables in the restrictive BIC and 5 variables in the AIC criteria. BIC criteria pre- 
Table 1. Summary (mean \pm SD) and comparison tests of significance (Kruskal-Wallis) of ecological metrics on fringing and island reefs in the western Indian Ocean showing (a) physical reef structure, (b) benthic cover, (c) sea urchin biomass and diversity, (d) herbivorous fish biomass, and (e) fish predators and predation index. $\chi^{2}$ is the chi-squared value and $p>\chi^{2}$ is the probability the comparison test is greater than random

\begin{tabular}{|c|c|c|c|c|}
\hline Variable & Fringing reef $(\mathrm{N}=108)$ & Island reef $(\mathrm{N}=73)$ & $\chi^{2}$ & $\mathrm{p}>\chi^{2}$ \\
\hline \multicolumn{5}{|l|}{ (a) Physical reef structure } \\
\hline Distance to shore $(\mathrm{km})$ & $1.08 \pm 1.46$ & $2.59 \pm 2.99$ & 12.86 & 0.0003 \\
\hline $\begin{array}{l}\text { Topographic complexity, straight line/bottom } \\
\text { contour distance }\left(\mathrm{m} \mathrm{m}^{-1}\right)\end{array}$ & $1.22 \pm 0.08$ & $1.23 \pm 0.06$ & 0.52 & 0.50 \\
\hline Acropora/massive Porites ratio & $3.47 \pm 8.88$ & $6.88 \pm 9.60$ & 23.5 & 0.0001 \\
\hline \multicolumn{5}{|l|}{ (b) Benthic cover $(\%)$} \\
\hline Hard coral & $27.87 \pm 15.88$ & $37.38 \pm 13.35$ & 17.04 & 0.0001 \\
\hline Algal turf & $35.53 \pm 12.15$ & $31.23 \pm 7.91$ & 4.47 & 0.03 \\
\hline Calcareous algae & $1.15 \pm 2.62$ & $0.45 \pm 0.78$ & 0.83 & 0.36 \\
\hline Fleshy algae & $14.93 \pm 14.58$ & $11.91 \pm 11$ & 1.31 & 0.25 \\
\hline Coralline algae & $9.52 \pm 6.94$ & $12.33 \pm 10.19$ & 1.46 & 0.23 \\
\hline Seagrass & $3.24 \pm 4.31$ & $0.51 \pm 1.02$ & 13.12 & 0.0003 \\
\hline Soft coral & $11.08 \pm 17.11$ & $9.62 \pm 8.86$ & 4.59 & 0.03 \\
\hline Sponge & $0.69 \pm 1.32$ & $0.8 \pm 1.39$ & 3.93 & 0.05 \\
\hline Sand & $7.1 \pm 6.7$ & $3.19 \pm 2.66$ & 8.11 & 0.004 \\
\hline Calcifying organisms & $38.15 \pm 15.32$ & $51.17 \pm 14.12$ & 16.03 & 0.0001 \\
\hline Non-calcifying organisms & $54.49 \pm 16.66$ & $45.64 \pm 13.97$ & 7.52 & 0.006 \\
\hline \multicolumn{5}{|l|}{ (c) Sea urchin biomass $\left(\mathrm{kg} \mathrm{ha}^{-1}\right)$} \\
\hline Diadema savignyi & $156.15 \pm 492.95$ & $328.15 \pm 680.43$ & 0.96 & 0.33 \\
\hline Diadema setosum & $279.46 \pm 847.9$ & $465.23 \pm 1119.3$ & 5.66 & 0.02 \\
\hline Echinometra mathaei & $667.8 \pm 1551.81$ & $35.76 \pm 124.96$ & 8.41 & 0.004 \\
\hline Echinostrephus molaris & $29.18 \pm 128.98$ & $16.89 \pm 36.95$ & 0.00 & 0.99 \\
\hline Echinothrix calamaris & $50.46 \pm 314.22$ & $14.01 \pm 36.28$ & 0.89 & 0.35 \\
\hline Echinothrix diadema & $616.45 \pm 1189.24$ & $559.97 \pm 950.05$ & 0.42 & 0.52 \\
\hline Toxopneustes pileolus & $4.39 \pm 14.6$ & $0.28 \pm 2.18$ & 11.83 & 0.001 \\
\hline Tripneustes gratilla & $126.38 \pm 289.83$ & $9.47 \pm 47.19$ & 17.21 & 0.0001 \\
\hline Stomopneustes variolaris & $1.21 \pm 4.71$ & 0 & 12.57 & 0.0004 \\
\hline Others & $0.06 \pm 0.58$ & 0 & 2.05 & 0.15 \\
\hline Diadematidae & $1052.06 \pm 1520.05$ & $1353.35 \pm 1692.59$ & 0.24 & 0.62 \\
\hline Total sea urchin biomass & $1931.54 \pm 2253.32$ & $1429.76 \pm 1730.97$ & 2.74 & 0.10 \\
\hline Sea urchin diversity, $D$ & $0.25 \pm 0.25$ & $0.26 \pm 0.24$ & 0.12 & 0.73 \\
\hline \multicolumn{5}{|l|}{ (d) Herbivorous fish biomass $\left(\mathrm{kg} \mathrm{ha}^{-1}\right)$} \\
\hline Acanthuridae & $109.28 \pm 119.85$ & $131.32 \pm 112.62$ & 4.75 & 0.03 \\
\hline Scaridae & $57.65 \pm 145.13$ & $69.49 \pm 73.8$ & 20.14 & 0.0001 \\
\hline Siganidae & $8.56 \pm 24.4$ & $10.39 \pm 33.23$ & 0.13 & 0.72 \\
\hline Total herbivorous fish biomass & $175.38 \pm 245.85$ & $211.2 \pm 165.8$ & 9.93 & 0.002 \\
\hline \multicolumn{5}{|l|}{ (e) Macro-invertebrate predators } \\
\hline Triggers and wrasses $>20 \mathrm{~cm}\left(\mathrm{~kg} \mathrm{ha}^{-1}\right)$ & $29.17 \pm 39.15$ & $55.21 \pm 51.86$ & 18.93 & 0.0001 \\
\hline Balistapus undulatus (ind. $500 \mathrm{~m}^{-2}$ ) & $0.71 \pm 1.08$ & $1.43 \pm 1.82$ & 10.78 & 0.001 \\
\hline Cheilinus trilobatus (ind. $500 \mathrm{~m}^{-2}$ ) & $1.01 \pm 1.03$ & $1.25 \pm 1.76$ & 0.08 & 0.78 \\
\hline Coris spp. (ind. $500 \mathrm{~m}^{-2}$ ) & $0.52 \pm 0.97$ & $0.47 \pm 0.77$ & 0.06 & 0.81 \\
\hline Lethrinus spp. (ind. $500 \mathrm{~m}^{-2}$ ) & $0.58 \pm 1.2$ & $0.52 \pm 1.29$ & 0.98 & 0.32 \\
\hline Predation index ( 0 to 1 ) & $0.22 \pm 0.25$ & $0.26 \pm 0.19$ & 3.54 & 0.06 \\
\hline
\end{tabular}

dicted a negative relationship with temperature skewness and weaker relationships with light and the global stress model and $11 \%$ of the variance was predicted. The AIC criteria explained $21 \%$ of the variance and the mean thermal stress anomaly and chlorophyll were positively associated, and suspended solids and global stress model were negatively associated, with coral cover. The mean thermal stress anomaly analyzed alone indicates a weak negative association with coral cover $\left(t=-2.06, \mathrm{p}<0.04, \mathrm{r}^{2}=0.02\right)$ but the relationship becomes positive after removing temperature skewness from the total variance. Consequently, thermal anomalies were not negatively influencing coral cover after accounting for temperature distribution properties. Therefore, temperature skewness was the strongest environmental factor by both criteria and in the final full model. The final full models also included Acropora/massive Porites ratio, Coris 
Table 2. Coral cover model results based on forward stepwise regression results for BIC and AIC stopping rules. Logit-transformed coral cover responses to sets of analyses, including (a) physical factors, (b) herbivores, (c) predators of macro-invertebrates, (d) satellite-derived environmental factors, and (e) all significant variables combined. The BIC stopping rules are presented only if not different from AIC results. Sections (f), (g), (h), and (i) present AIC results that were different from BIC results. Results are based on analysis of 168 study site replicates. Echino/Diade $=$ Echinometridae/Diadematidae; VIF $=$ variance inflation factor; $\mathrm{p}>\mathrm{F}$ is the probability the comparison test is greater than random; $\mathrm{SST}=$ sea surface temperature; NS $=$ not significant. VIF only reported when more than one factor is significant. When no values are given, they are not significant

\begin{tabular}{|c|c|c|c|c|c|c|c|}
\hline Parameter & Estimate (mean $\pm \mathrm{SE}$ ) & $t$-ratio & F-ratio & $\mathrm{p}>|t|$ & VIF & $\mathrm{R}^{2}$ & $\mathrm{p}>F$ \\
\hline \multicolumn{8}{|l|}{$\begin{array}{l}\text { BIC STOPPING RULES } \\
\text { (a) Physical factors }\end{array}$} \\
\hline Intercept & $-0.10 \pm 0.07$ & -13.37 & 0.0 & 0.0001 & & 0.17 & $<0.0001$ \\
\hline Acropora/massive Porites ratio & $0.03 \pm 0.01$ & 4.03 & 14.03 & 0.0001 & 1.03 & & \\
\hline Reef type (fringing) & $-0.23 \pm 0.07$ & -3.43 & 6.35 & 0.0008 & 1.03 & & \\
\hline Distance to shore $(\mathrm{km})$ & & & 3.39 & NS & & & \\
\hline Exposed vs. sheltered & & & 2.29 & NS & & & \\
\hline Depth (m) & & & 1.68 & NS & & & \\
\hline Rugosity $\left(\mathrm{m} \mathrm{m}^{-1}\right)$ & & & 0.10 & NS & & & \\
\hline \multicolumn{8}{|l|}{ (b) Herbivore metrics (kg ha-1) } \\
\hline Intercept & $-0.81 \pm 0.07$ & -11.85 & 0.0 & 0.0001 & & 0.08 & 0.002 \\
\hline Echinometra mathaei & $-0.0003 \pm 0.0001$ & -3.76 & 13.05 & 0.0002 & & & \\
\hline Acanthuridae & & & 4.08 & NS & & & \\
\hline Herbivorous fish & & & 3.49 & NS & & & \\
\hline Diadematidae & & & 2.05 & NS & & & \\
\hline Scaridae & & & 1.66 & NS & & & \\
\hline Echino/Diade weighted ratio & & & 0.17 & NS & & & \\
\hline Siganidae & & & 0.07 & NS & & & \\
\hline \multicolumn{8}{|c|}{ (c) Predators of macro-invertebrates (ind. $500 \mathrm{~m}^{-2}$ or $\mathrm{kg} \mathrm{ha}^{-1}$ ) } \\
\hline Intercept & $-0.91 \pm 0.09$ & -9.83 & 0.0 & 0.0001 & & 0.10 & 0.0003 \\
\hline Coris spp. & $-0.25 \pm 0.07$ & -3.33 & 9.21 & 0.001 & 1.0 & & \\
\hline Balistapus undulatus & $0.13 \pm 0.06$ & 2.37 & 8.33 & 0.02 & 1.0 & & \\
\hline Cheilinus trilobatus & & & 1.10 & NS & & & \\
\hline Lethrinus spp. & & & 0.42 & NS & & & \\
\hline Triggers and wrasses & & & 0.02 & NS & & & \\
\hline \multicolumn{8}{|l|}{ (d) Environmental variables } \\
\hline Intercept & $-0.72 \pm 0.08$ & -9.12 & 0.0 & 0.0001 & & 0.11 & 0.0001 \\
\hline SST skewness & $-1.37 \pm 0.3$ & -4.62 & 21.34 & 0.0001 & & & \\
\hline PAR median $\left(\mathrm{E} \mathrm{m}^{-2} \mathrm{~d}^{-1}\right)$ & & & 4.45 & 0.04 & & & \\
\hline Global stress model & & & 3.64 & 0.06 & & & \\
\hline Suspended solids median $\left(\mathrm{g} \mathrm{m}^{-3}\right)$ & & & 2.88 & 0.1 & & & \\
\hline Mean thermal stress anomaly $\left({ }^{\circ} \mathrm{C}\right)$ & & & 2.76 & 0.1 & & & \\
\hline $\mathrm{SST}$ median $\left({ }^{\circ} \mathrm{C}\right)$ & & & 0.92 & NS & & & \\
\hline Chlorophyll median $\left(\mathrm{mg} \mathrm{m}^{-3}\right)$ & & & 0.68 & NS & & & \\
\hline Climate exposure & & & 0.27 & NS & & & \\
\hline SST kurtosis & & & 0.01 & NS & & & \\
\hline \multicolumn{8}{|l|}{ (e) Full model } \\
\hline Intercept & $-0.79 \pm 0.10$ & -8.25 & 0.0 & 0.0001 & & 0.21 & 0.0001 \\
\hline SST skewness & $-1.09 \pm 0.31$ & -3.54 & 12.51 & 0.0005 & 1.09 & & \\
\hline Acropora/massive Porites ratio & $0.02 \pm 0.01$ & 3.28 & 10.74 & 0.001 & 1.09 & & \\
\hline Coris spp. & $-0.17 \pm 0.07$ & -2.31 & 5.35 & 0.02 & 1.05 & & \\
\hline Reef type (fringing) & & & 4.16 & 0.04 & & & \\
\hline Balistapus undulatus & & & 3.62 & 0.06 & & & \\
\hline Echinometra mathaei & & & 0.52 & NS & & & \\
\hline \multicolumn{8}{|l|}{ AIC STOPPING RULES } \\
\hline Intercept & $-0.86 \pm 0.07$ & -9.24 & 0.0 & 0.0001 & & 0.20 & 0.0001 \\
\hline Acropora/massive Porites ratio & $0.03 \pm 0.01$ & 3.88 & 12.95 & 0.0001 & 1.04 & & \\
\hline Reef type (fringing) & $-0.29 \pm 0.07$ & -4.13 & 9.07 & 0.0008 & 1.20 & & \\
\hline Distance to shore $(\mathrm{km})$ & $-0.07 \pm 0.03$ & -2.43 & 3.39 & 0.02 & 1.16 & & \\
\hline Depth (m) & & & 1.49 & NS & & & \\
\hline Exposure & & & 1.26 & NS & & & \\
\hline Rugosity ( $\mathrm{m} \mathrm{m}^{-1}$ ) & & & 0.10 & NS & & & \\
\hline
\end{tabular}


Table 2. Continued

\begin{tabular}{|c|c|c|c|c|c|c|c|}
\hline Parameter & Estimate (mean $\pm \mathrm{SE})$ & $t$-ratio & F-ratio & $\mathrm{p}>|t|$ & VIF & $\mathrm{R}^{2}$ & $\mathrm{p}>F$ \\
\hline \multicolumn{8}{|l|}{ (g) Herbivore metrics $\left(\mathrm{kg} \mathrm{ha}^{-1}\right)$} \\
\hline Intercept & $-0.69 \pm 0.10$ & -6.87 & 0.0 & 0.0001 & & 0.11 & 0.0003 \\
\hline Echinometra mathaei & $-0.0004 \pm 0.0001$ & -4.02 & 16.15 & 0.0001 & 1.06 & & \\
\hline Acanthuridae & $-0.001 \pm 0.001$ & -2.02 & 4.08 & 0.04 & 1.06 & & \\
\hline Diadematidae & & & 1.00 & NS & & & \\
\hline Echino/Diade weighted ratio & & & 0.27 & NS & & & \\
\hline Scaridae & & & 0.22 & NS & & & \\
\hline Herbivorous fish & & & 0.17 & NS & & & \\
\hline Siganidae & & & 0.00 & NS & & & \\
\hline \multicolumn{8}{|l|}{ (h) Environmental variables } \\
\hline Intercept & $2.62 \pm 1.52$ & 1.72 & 0.0 & 0.09 & & 0.21 & 0.0001 \\
\hline SST skewness & $-1.97 \pm 0.43$ & -4.62 & 21.31 & 0.0001 & 2.29 & & \\
\hline Mean thermal stress anomaly & $0.09 \pm 0.03$ & 2.51 & 6.29 & 0.01 & 2.50 & & \\
\hline Chlorophyll median $\left(\mathrm{mg} \mathrm{m}^{-3}\right)$ & $1.83 \pm 0.73$ & 2.50 & 6.23 & 0.01 & 7.68 & & \\
\hline Suspended solids median $\left(\mathrm{g} \mathrm{m}^{-3}\right)$ & $-2.00 \pm 0.91$ & -2.20 & 4.85 & 0.03 & 6.74 & & \\
\hline Global stress model & $-1.31 \pm 0.74$ & -1.78 & 3.16 & 0.08 & 2.42 & & \\
\hline PAR median $\left(\mathrm{E} \mathrm{m}^{-2} \mathrm{~d}^{-1}\right)$ & $-0.05 \pm 0.04$ & -1.49 & 2.23 & NS & 1.69 & & \\
\hline SST median $\left({ }^{\circ} \mathrm{C}\right)$ & & & 0.15 & NS & & & \\
\hline Climate exposure & & & 0.02 & NS & & & \\
\hline SST kurtosis & & & 0.003 & NS & & & \\
\hline \multicolumn{8}{|l|}{ (i) Full model } \\
\hline Intercept & $-1.15 \pm 0.22$ & -5.14 & 0.0 & 0.0001 & & 0.27 & 0.0001 \\
\hline SST skewness & $-1.72 \pm 0.42$ & -4.11 & 16.91 & 0.0001 & 2.15 & & \\
\hline Acropora/massive Porites ratio & $0.03 \pm 0.01$ & 3.78 & 14.32 & 0.0002 & 1.18 & & \\
\hline Acanthuridae & $-0.001 \pm 0.001$ & -2.07 & 4.30 & 0.04 & 1.17 & & \\
\hline Mean thermal stress anomaly & $0.06 \pm 0.03$ & 2.00 & 4.00 & 0.05 & 2.23 & & \\
\hline Balistapus undulatus & $0.10 \pm 0.05$ & 1.96 & 3.85 & 0.05 & 1.13 & & \\
\hline Coris spp. & $-0.12 \pm 0.07$ & -1.74 & 3.04 & 0.08 & 1.08 & & \\
\hline Distance to shore $(\mathrm{km})$ & & & 1.10 & NS & & & \\
\hline Reef type (fringing) & & & 0.99 & NS & & & \\
\hline Chlorophyll median & & & 0.57 & NS & & & \\
\hline Echinometra mathaei & & & 0.19 & NS & & & \\
\hline Suspended solids median $\left(\mathrm{g} \mathrm{m}^{-3}\right)$ & & & 0.02 & NS & & & \\
\hline
\end{tabular}

spp., and B. undulatus for both criteria. The AIC also included Acanthuridae and the thermal stress anomaly but excluded reef type, which was included in the final BIC model.

\section{Calcifier cover relationships}

There were no differences in BIC and AIC criteria results for calcifier cover-predictor variable relationships. The Acropora/massive Porites cover ratio and reef type were the 2 significant physical factors and predicated $29 \%$ of the variance (Table 3, Fig. 3). Among the herbivores, only the abundance of E. mathaei biomass was significant, negatively associated with calcifier cover, and predicted $29 \%$ of the variance. Among the carnivores, the number of $B$. undulatus was positively associated with calcifier cover and, combined with a negative association with Coris wrasses, predicted $20 \%$ of the variance. Among the environmental variables, SST kurtosis was most negatively associ- ated with calcifier cover and, together with skewness, explained $37 \%$ of the variance. The final full model found $B$. undulatus abundance was the strongest variable, followed by SST skewness, Coris spp., and SST kurtosis.

\section{DISCUSSION}

This large-scale study indicates the relative importance of a number of factors predicted to influence hard coral and all calcifiers. While regression analysis has limits to developing truly causative and predictive models, uncovering association and inclusion criteria is valuable for comparing existing information and planning future experimental research. For example, failure to find associations in regression analyses can indicate that hypotheses that predict causation are probably not well founded. Consequently, insignificant findings provide a basis for modifying hypotheses and developing experiments needed to better understand causation. The existing 
Table 3. Calcifier cover model results based on forward stepwise regression analyses for BIC stopping rules. Logit-transformed coral cover responses to sets of analyses, including (a) physical factors, (b) herbivores, (c) predators of macro-invertebrates, (d) satellite-derived environmental factors, and (e) all significant variables combined. Results are based on analysis of 97 study site replicates. Echino/Diade $=$ Echinometridae/Diadematidae; VIF = variance inflation factor; $\mathrm{p}>F$ is the probability the comparison test is greater than random; SST = sea surface temperature; NS = not significant. VIF only reported when more than one factor is significant. When no values are given, they are not significant

\begin{tabular}{|c|c|c|c|c|c|c|c|}
\hline Parameter & Estimate (mean $\pm \mathrm{SE})$ & $t$-ratio & $F$-ratio & $\mathrm{p}>|t|$ & VIF & $\mathrm{R}^{2}$ & $\mathrm{p}>F$ \\
\hline \multicolumn{8}{|l|}{ (a) Physical factors } \\
\hline Intercept & $-0.40 \pm 0.08$ & -5.33 & 0.0 & 0.0001 & & 0.29 & 0.0001 \\
\hline Acropora/massive Porites ratio & $0.02 \pm 0.01$ & 4.27 & 17.45 & 0.0001 & 1.02 & & \\
\hline Reef type (fringing) & $-0.25 \pm 0.07$ & -3.68 & 14.74 & 0.0004 & 1.02 & & \\
\hline Exposed vs. sheltered & & & 1.80 & NS & & & \\
\hline Depth (m) & & & 1.39 & NS & & & \\
\hline Distance to shore (km) & & & 0.39 & NS & & & \\
\hline Rugosity (m m-1) & & & 0.13 & NS & & & \\
\hline \multicolumn{8}{|l|}{ (b) Herbivore metrics $\left(\mathrm{kg} \mathrm{ha}^{-1}\right)$} \\
\hline Intercept & $-0.20 \pm 0.07$ & -1.71 & 0.0 & 0.09 & & 0.29 & 0.0001 \\
\hline Echinometra mathaei & $-0.0004 \pm 0.0001$ & -5.86 & 30.49 & 0.0001 & & & \\
\hline Siganidae & & & 1.04 & NS & & & \\
\hline Acanthuridae & & & 0.14 & NS & & & \\
\hline Echino/Diade weighted ratio & & & 0.08 & NS & & & \\
\hline Diadematidae & & & 0.001 & NS & & & \\
\hline Scaridae & & & 0.0 & NS & & & \\
\hline Herbivorous fish & & & 0.0 & NS & & & \\
\hline \multicolumn{8}{|c|}{ (c) Predators of macro-invertebrates (ind. $500 \mathrm{~m}^{-2}$ ) } \\
\hline Intercept & $-0.32 \pm 0.09$ & -3.58 & 0.0 & 0.001 & & 0.20 & 0.0001 \\
\hline Balistapus undulatus & $0.32 \pm 0.08$ & 3.81 & 23.25 & 0.0003 & 1.01 & & \\
\hline Coris spp. & $-0.24 \pm 0.08$ & -3.13 & 7.63 & 0.002 & 1.01 & & \\
\hline Lethrinus spp. & & & 1.01 & NS & & & \\
\hline Cheilinus trilobatus & & & 0.60 & NS & & & \\
\hline Triggers and wrasses & & & 0.47 & NS & & & \\
\hline \multicolumn{8}{|l|}{ (d) Environmental variables } \\
\hline Intercept & $-0.35 \pm 0.16$ & -2.12 & 0.0 & 0.04 & & 0.37 & 0.0001 \\
\hline SST kurtosis & $-0.58 \pm 0.21$ & -2.76 & 8.28 & 0.007 & 2.12 & & \\
\hline SST skewness & $-1.08 \pm 0.4$ & -2.69 & 6.71 & 0.007 & 2.12 & & \\
\hline Global stress model & & & 0.92 & NS & & & \\
\hline Suspended solids median $\left(\mathrm{g} \mathrm{m}^{-3}\right)$ & & & 0.69 & NS & & & \\
\hline Mean thermal stress anomaly $\left({ }^{\circ} \mathrm{C}\right)$ & & & 0.57 & NS & & & \\
\hline PAR median $\left(\mathrm{E} \mathrm{m}^{-2}\right.$ day $\left.^{-1}\right)$ & & & 0.36 & NS & & & \\
\hline Chlorophyll median $\left(\mathrm{mg} \mathrm{m}^{-3}\right.$ ) & & & 0.12 & NS & & & \\
\hline $\mathrm{SST}$ median $\left({ }^{\circ} \mathrm{C}\right)$ & & & 0.11 & NS & & & \\
\hline Climate exposure & & & 0.03 & NS & & & \\
\hline \multicolumn{8}{|l|}{ (e) Full model } \\
\hline Intercept & $-0.35 \pm 0.17$ & -2.04 & 0.0 & 0.04 & & 0.47 & 0.0001 \\
\hline Balistapus undulatus & $0.27 \pm 0.07$ & 3.85 & 14.82 & 0.0002 & 1.02 & & \\
\hline SST skewness & $-1.04 \pm 0.40$ & -2.62 & 6.85 & 0.01 & 2.16 & & \\
\hline Coris spp. & $-0.15 \pm 0.07$ & -2.32 & 5.39 & 0.02 & 1.07 & & \\
\hline SST kurtosis & $-0.48 \pm 0.21$ & -2.31 & 5.35 & 0.02 & 2.22 & & \\
\hline Reef type & & & 1.21 & NS & & & \\
\hline Acropora/massive Porites ratio & & & 0.88 & NS & & & \\
\hline Echinometra mathaei & & & 0.53 & NS & & & \\
\hline
\end{tabular}

experimental and correlational literature also form a basis for interpreting findings from regression analyses, which can help distinguish potentially competing hypotheses. Finally, evaluating many factors expands the practical limits of experimental studies. Here, we found that there are many likely influences on corals and calcifiers and yet even the best multivariate models explained no more than half of the between-site variance for calcifiers and one quarter for corals. This indicates the complexity of the coral reef environment and the possible role of factors not measured here. 

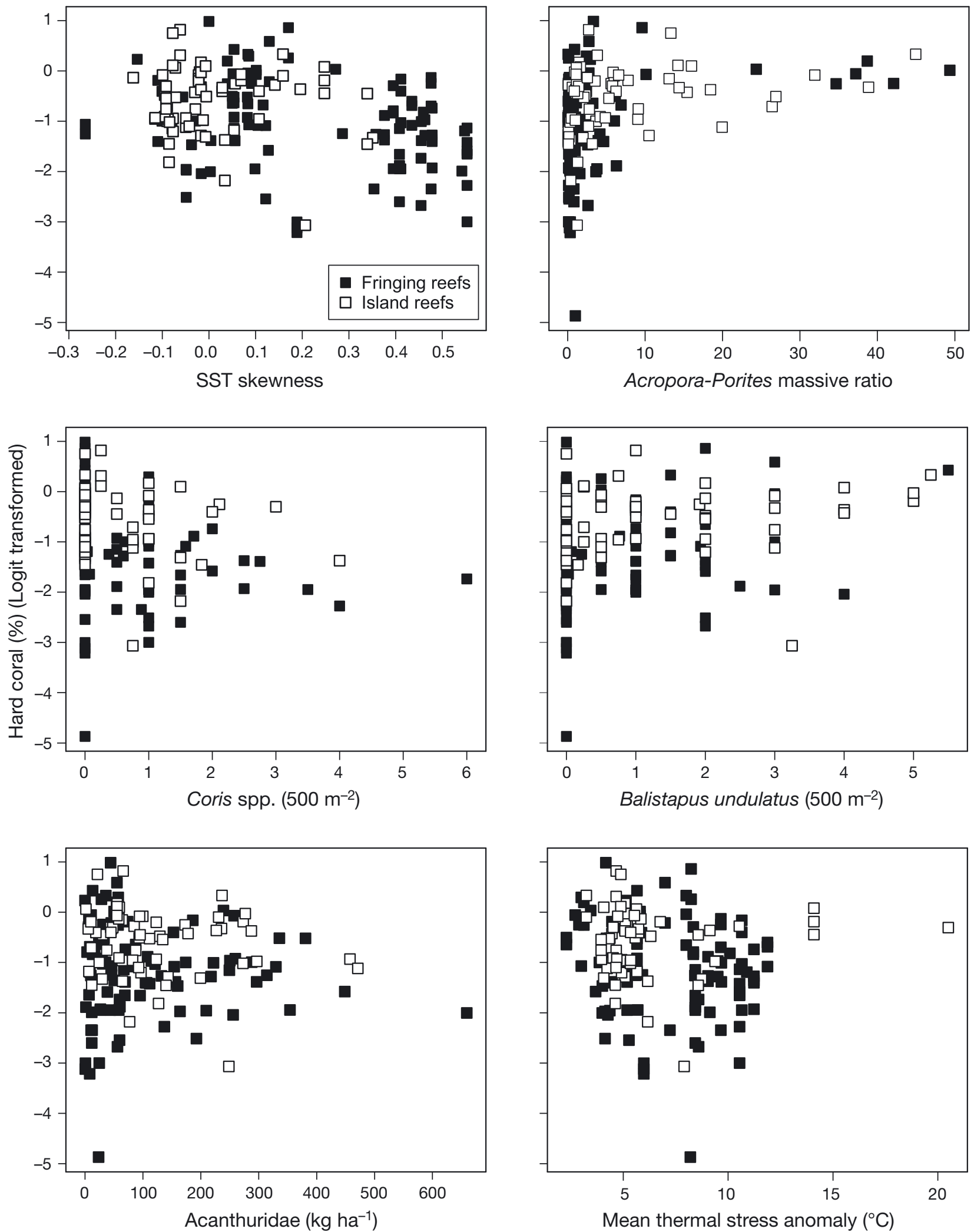

Fig. 2. Scatterplots of significant environmental and ecological relationships for coral cover, distinguishing fringing and island reefs 

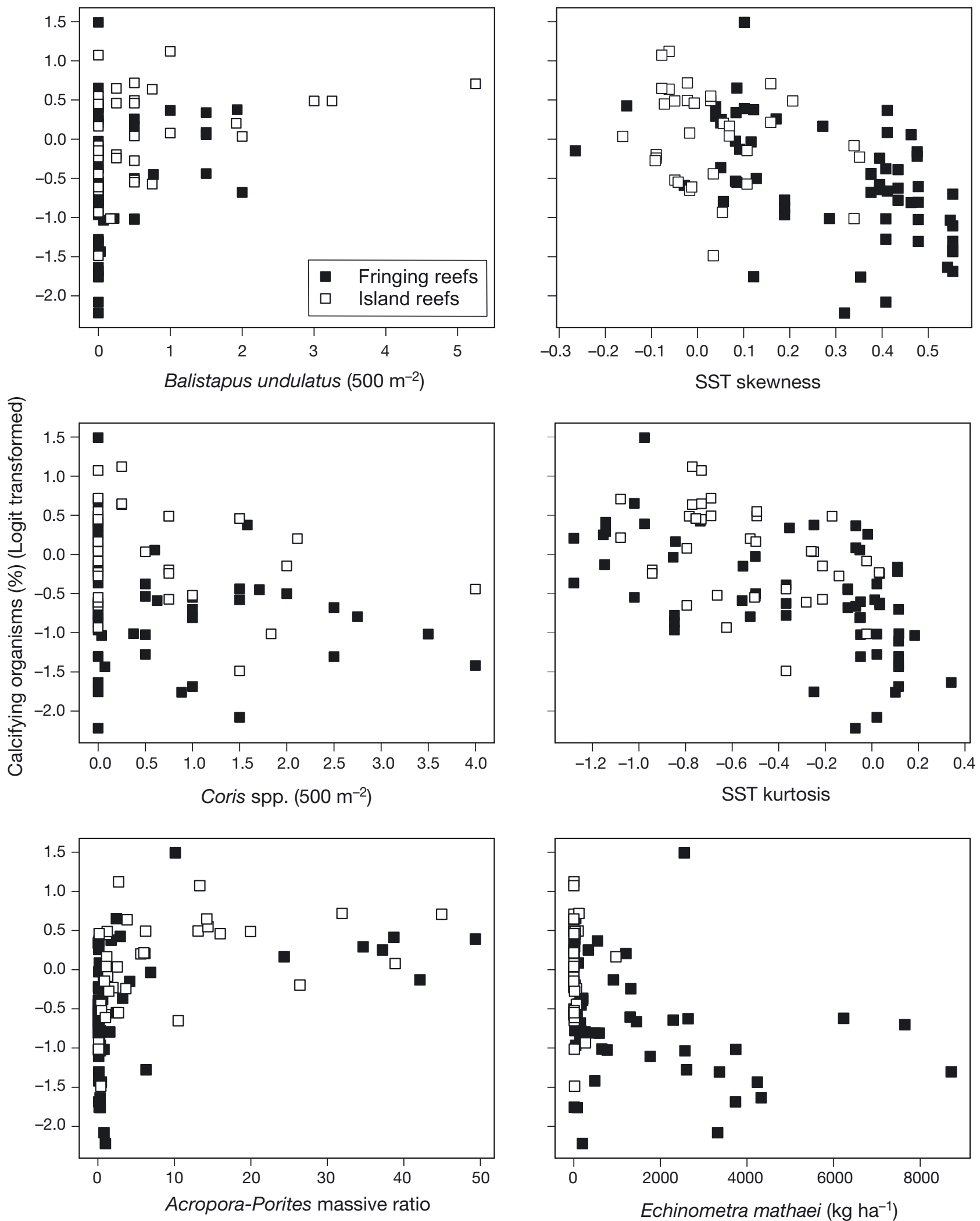

Fig. 3. Scatterplots of significant environmental and ecological relationships for calcifier cover, distinguishing fringing and island reefs 
Satellite-derived environmental variables associated with thermal variation were among the dominant influences associated with both coral and calcifiers. This is likely to reflect a history of environmental stress and the associated change and adaptation (Ateweberhan \& McClanahan 2010). For example, the right skew in temperature distribution was most strongly negatively associated with coral cover and also for all calcifiers. Skewness and kurtosis were positively correlated $(\mathrm{r}=0.80)$ and both were positively associated with the various thermal stress anomalies (skewness vs. mean thermal stress $=0.71$, kurtosis vs. mean thermal stress $=0.82$ ). Consequently, anomalies can be seen as key factors that reflect SST disturbances but there were, for example, opposite influences with right skewness having a negative and the mean thermal stress anomaly having a positive association with coral cover once the skewness variance was removed. This suggests that anomalies are less important than background temperatures for determining whether or not an anomaly is detrimental to corals (McClanahan et al. 2007b). Flat temperature distributions or negative kurtosis was positively associated with coral cover and this is expected based on proposed anomaly/acclimation mechanisms (Ateweberhan \& McClanahan 2010).

The Acropora/massive Porites ratio and reef type were the physical features that were significantly related to coral and calcifier cover, with higher coral and calcifying cover on island than fringing reefs. Island reefs had about twice the Acropora/massive Porites ratios than fringing reefs and this is likely to explain the higher estimated calcification rates on islands (Perry et al. 2015). While direct comparisons indicate that coral cover was $\sim 40 \%$ and calcifying cover $\sim 30 \%$ higher on island than fringing reefs, the step-wise regression indicates that these 2 variables explained $<30 \%$ of the total variance. The distance to shore was expected to influence corals and calcifiers due to reduced anthropogenic impacts of fishing, dive tourism, and water quality offshore (Fabricius 2005, Smith et al. 2008, Brewer et al. 2013). Nevertheless, we failed to find any strong onshoreoffshore influences, which may be due to the limited range of distances ( 0.02 to $10.6 \mathrm{~km})$ and the sites' mean closeness to shore. Nevertheless, other studies have failed to find strong patterns of coral degradation with distance from shore (Lirman \& Fong 2007, Bruno \& Valdivia 2016) while others have found higher calcifier but not coral cover in remote Pacific reefs (Smith et al. 2016). Climate and warm water impacts, which have been widespread, may have played a role in these patterns where reefs lacked the capacity to tolerate stress (McClanahan et al. 2015a). Yet, the thermal anomalies were positively rather than negatively related to coral cover after accounting for temperature skewness in our study. Because coral cover generally recovers within $10 \mathrm{yr}$, the impacts of thermal disturbances to corals maybe shortlived (Ateweberhan et al. 2011, Gilmour et al. 2013). Consequently, high variation in the time since thermal disturbance is a likely reason the global stress model had a weak relationship with coral cover. Our data were collected over many years during a period of thermal stress but without knowledge of when each site was disturbed by the stresses (McClanahan et al. 2015a).

The grazer community and their biomass were hypothesized to influence coral and calcifier patterns. Given the hypothesized grazer role in promoting coral by controlling algal-coral relationships and subsequent fishing restriction recommendations, this result is unexpected (Lewis 1986, Hughes et al. 2003, Mumby et al. 2006, Game et al. 2009, Bellwood et al. 2012, Rasher et al. 2012, Edwards et al. 2014). Here, we found no evidence that any herbivorous fish were positively associated with calcifiers. The one weak association was a negative association between acanthurids and coral cover that would indicate their preference for feeding on dead coral surfaces (Marshell \& Mumby 2012). While this does not support some ecosystem management recommendations, it does correspond with a number of large-scale studies that have failed to find significant coralparrotfish associations, identified other factors, or found that herbivorous fish passively associate with, rather than actively control, algae-coral relationships (McClanahan et al. 2011b, Wilson et al. 2012, Carassou et al. 2013, Graham et al. 2015, Russ et al. 2015, Suchley et al. 2016).

The lack of biomass differences in surgeonfish and parrotfish between reef types suggests that their influence was weak and also not habitat specific. Parrotfish impacts are suggested to differ between hard and soft coral dominated ecosystems (Mumby 2016) but Indian Ocean reefs have few reefs dominated by soft corals. Overall, parrotfish biomass was low in most of the studied reefs and previous studies suggest they recover slowly ( $>10 \mathrm{yr}$ ) from fishing in this region's no-take closures (McClanahan et al. 2007C, McClanahan \& Humphries 2012). Consequently, while herbivorous fish may contribute to grazing and the promotion of calcifiers, the $B$. undulatus-E. mathaei cascade could override any positive effects herbivorous fish may have on calcifier cover. A number of regional studies indicate that grazing is 
influenced by a high diversity of grazing functional groups, not just fish (Humphries et al. 2014, McClanahan 2014). If so, it may be that diversity and redundancy provide some of the capacity to maintain grazing and calcifier cover but each grazer species or functional group provides only a small and difficult to detect impact (Thibaut \& Connolly 2013).

It is likely that a combination of factors influenced the ecological outcomes including the well-studied fishing-macro-invertebrate predator-sea urchin herbivore-calcifier trophic cascade (McClanahan \& Shafir 1990, O'Leary \& McClanahan 2010). The triggerfish $B$. undulatus was included in most significant regression models, including the restrictive BIC models. Further, difference between reef types may be due to higher abundance of $B$. undulatus and Acropora on island than fringing reefs. Predation rates on tethered E. mathaei were not, however, very different between island and fringing reefs. Yet, E. mathaei was considerably more abundant on fringing than island reefs. Consequently, E. mathaei may benefit from other habitat characteristics of fringing reefs and taxa-specific nuances in the abundance and ratio of Echinometridae/Diadematidae and Acropora/massive Porites that could be important in explaining the higher calcifier cover on island reefs. Given the role of reef type in mediating these key coral and sea urchin taxa and the trophic cascade, it is also expected that calcification rates will differ between reef types (Koweek et al. 2015).

Why reef type creates these differences in the dominant corals, fish taxa and reef process is unlikely to be clarified without further study; but the combination of substrate consolidation, isolation, waves, and water flow are likely to be key explanatory factors. For example, distribution studies of Diadema and Echinometra often emphasize the greater abundance of Echinometra in high water flow environments receiving algal drift common to fringing reefs and Diadema in environments with more limited water flow (Russo 1977, Tuya et al. 2007, Bronstein \& Loya 2014). Perry et al. (2015) also reported that Porites community cover is higher in high water flow environments than Acropora dominated reefs in the central Indian Ocean. Consequently, high water flow is likely to be promoting Porites and E. mathaei and low water flow Acropora and Diadema dominance. While reef exposure was not important relative to reef type, high numbers of E. mathaei were observed in the shallow and wave-protected leeward sides of fringing reefs (McClanahan \& Kurtis 1991). This suggests breaking waves versus water flow have some unmeasured influences in the observed patterns. It was common to observe high numbers of the 2 Echinothrix species at depth or in high water flow environments without waves. Therefore, these habitat, wave, water flow, and depth variables are likely to be influencing the niches of these sea urchins with possible consequences for calcifiers (McClanahan \& Muthiga 2016).

Some combination of unmeasured environmental factors and higher Diadematidae grazing relative to Echinometridae on island reefs may influence coral and calcifier cover. Numerous studies of grazing by sea urchins on coral and algae indicate that, at moderate abundance, sea urchins reduce algae and this promotes coral recruitment (Edmunds \& Carpenter 2001), but other studies indicate negative effects of sea urchin grazing on corals and their recruits at moderate to high sea urchin grazing (Sammarco 1980, O'Leary et al. 2012, 2014, Qiu et al. 2014). Lower coral recruitment could be due to lower coralline algae cover in urchin-dominated reefs but we found no difference in coralline algal cover between island and fringing reefs. No published studies have successfully separated the grazing and densitydependent effects of Echinometra and Diadema on coral recruitment or coralline and coral cover. Consequently, our findings identify these experiments as an important area for future study. A companion study found differences in coral cover associated with the 2 dominant species of Diadema, with higher coral cover associated with the less common $D$. setosum compared to D. savignyi (McClanahan \& Muthiga 2016). Consequently, evaluating species-level differences may be important for understanding ecological outcomes for calcifers.

Many of the dominant environmental and ecological factors expected to influence calcifier cover were studied but potentially important factors such as water flow, nutrient concentrations, fishing or destructive gear use, and the common problem of attributing correlation to causation remain potential weaknesses of this study. One likely example of a false correlation-causation problem is the consistent association between Coris wrasses and low coral cover. The Coris recorded here were largely juveniles, and we suggest the association occurs because juvenile Coris are commonly observed feeding on small invertebrates or foraging on dead invertebrate carcasses in low coral cover, sand, and rubble environments. Direct negative or indirect effects of Coris on corals have not been observed or expected and it is more likely that Coris are scavengers on dead $E$. mathaei in low coral cover reefs. Juvenile Coris wrasses are competitively subordinate to $B$. undula- 
tus in sea urchin feeding experiments, Coris mostly scavenge on sea urchin carcasses, but in the absence of $B$. undulatus due to fishing, Coris are relatively more common predators (McClanahan 2000).

The same habitat-association patterns could explain the positive association between $B$. undulatus and coral cover. While $B$. undulatus hides in coral and other crevices, there is direct observational evidence that they control sea urchin populations (McClanahan 2000, 2014). Additionally, studies where fishing has been stopped have shown that when $B$. undulatus numbers increase, sea urchin numbers and their feeding impacts on coralline algal cover decline (O'Leary \& McClanahan 2010, O'Leary et al. 2012, 2014, McClanahan 2014). Consequently, while the high spatial and temporal replication of this study and the restrictive BIC criteria is likely to reduce the chances of spurious statistical associations, consistent fish-habitat associations can mistakenly imply causation. Consequently, observation and experimental results are needed to support regression analysis studies. Future tests of the proposed cascade impact will require experimental or applied management research where $B$. undulatus populations are manipulated and the long-term ecological consequences evaluated.

The implication of this and related studies is that the interaction between reef type, sea urchin associations, and the feeding behavior of $B$. undulatus produces differences in grazing sea urchins with consequences for benthic calcifiers. Calcification and reef growth is a threatened ecological service that requires management to prevent its further loss from current and projected climate disturbances (Cooper et al. 2008, De'ath et al. 2009, Tanzil et al. 2009, 2013, Kennedy et al. 2013, Silverman et al. 2014) but can vary and be less threatened depending on other factors, such as habitat and latitude (McClanahan et al. 2005, 2007a, Golbuu et al. 2007, Cantin et al. 2010, Cooper et al. 2012). The western Indian Ocean region has been influenced by temperature anomalies that have reduced coral cover in many places, but some mortality has been followed by recovery and shifts in the dominant coral taxa (McClanahan et al. 2014). In some cases, losses of coral cover are followed by increases in coralline algal cover, which may help to stabilize the calcifying community (O'Leary \& McClanahan 2010).

The patterns described here indicate a food webhabitat mechanism potentially influential in the maintenance of reef calcifiers and amenable to management with some capacity to compensate for the negative effects of climate disturbances on calcification. The maintenance or protection of $B$. undulatus populations is a species-specific management recommendation arising from this research. The study also suggests that island reefs have greater potential to promote calcification because of the interactions between reef type, $B$. undulatus, and sea urchin grazer dominance. This knowledge may be useful for planning and prioritizing reef management restrictions that favor the persistence of reef calcification. Regardless, policy and management priorities will need to consider interactions between climate and reef ecology.

Acknowledgements. We thank the national institutions for their logistical support in each of the studied reefs and greatly appreciate the assistance of many people in the field, information retrieval, and data analysis, notably R. Albright, M. Azali, H. Machano Ali, A. Guissamulo, F. JanuchowskiHartley, A. T. Kamukuru, J. M. Maina, R. Moothien-Pillay, M. J. Rodrigues, B. Radrimananstoa and I. Marquis da Silva. The various projects that lead to the compilation of the large data set were supported by the John D. and Catherine T. MacArthur Foundation, The Tiffany \& Co. Foundation, United States Agency for International Development, the Western Indian Ocean Marine Science Association's Marine Science for Management Program, the Ecosystem Services for Poverty Alleviation (ESPA) programme of the Department for International Development (DFID), the Economic and Social Research Council (ESRC) and the Natural Environment Research Council (NERC), research grant NE-K010484-1.

\section{LITERATURE CITED}

Albright R, Langdon C, Anthony KRN (2013) Dynamics of seawater carbonate chemistry, production, and calcification of a coral reef flat, central Great Barrier Reef. Biogeosciences 10:6747-6758

Andersson AJ, Gledhill D (2013) Ocean acidification and coral reefs: effects on breakdown, dissolution, and net ecosystem calcification. Annu Rev Mar Sci 5:321-348

Ateweberhan M, McClanahan TR (2010) Relationship between historical sea-surface temperature variability and climate change-induced coral mortality in the Western Indian Ocean. Mar Pollut Bull 60:964-970

> Ateweberhan M, McClanahan TR (2016) Partitioning scleractinian coral diversity across reef sites and regions in the Western Indian Ocean. Ecosphere 7:e01243

> Ateweberhan M, McClanahan TR, Graham NAJ, Sheppard C (2011) Episodic heterogeneous decline and recovery of coral cover in the Western Indian Ocean. Coral Reefs 30: 739-752

Bell JD, Ganachaud A, Gehrke PC, Griffiths SP and others (2013) Mixed responses of tropical Pacific fisheries and aquaculture to climate change. Nat Clim Change 3: 591-599

Bellwood DR, Hoey AS, Hughes TP (2012) Human activity selectively impacts the ecosystem roles of parrotfishes on coral reefs. Proc R Soc B 279:1621-1629

Brewer TD, Cinner JE, Green A, Pressey RL (2013) Effects of human population density and proximity to markets on coral reef fishes vulnerable to extinction by fishing. Conserv Biol 27:443-452 
Bronstein O, Loya Y (2014) Echinoid community structure and rates of herbivory and bioerosion on exposed and sheltered reefs. J Exp Mar Biol Ecol 456:8-17

Bruno JF, Valdivia A (2016) Coral reef degradation is not correlated with local human population density. Sci Rep 6: 29778

Burkepile DE, Hay ME (2010) Impact of herbivore identity on algal succession and coral growth on a Caribbean reef. PLOS ONE 5:e8963

Burnham KP, Anderson DR (2002) Model selection and inference-a practical information-theoretic approach. Springer-Verlag, New York, NY

> Cantin NE, Cohen AL, Karnauskas KB, Tarrant AM, McCorkle DC (2010) Ocean warming slows coral growth in the central Red Sea. Science 329:322-325

Carassou L, Leopold M, Guillemot N, Wantiez L, Kulbicki M (2013) Does herbivorous fish protection really improve coral reef resilience? A case study from New Caledonia (South Pacific). PLOS ONE 8:e60564

> Carreiro-Silva M, McClanahan TR (2012) Macrobioerosion of dead branching Porites, 4 and 6 years after coral mass mortality. Mar Ecol Prog Ser 458:103-122

> Chollett I, Mumby PJ (2013) Reefs of last resort: locating and assessing thermal refugia in the wider Caribbean. Biol Conserv 167:179-186

> Cooper TF, De'ath G, Fabricius KE, Lough JM (2008) Declining coral calcification in massive Porites in two nearshore regions of the northern Great Barrier Reef. Glob Change Biol 14:529-538

Cooper TF, O'Leary RA, Lough JM (2012) Growth of Western Australian corals in the Anthropocene. Science 335: 593-596

> De'ath G, Lough JM, Fabricius KE (2009) Declining coral calcification on the Great Barrier Reef. Science 323:116-119

Edmunds PJ, Carpenter RC (2001) Recovery of Diadema antillarum reduces macroalgal cover and increases abundance of juvenile corals on a Caribbean reef. Proc Natl Acad Sci USA 98:5067-5071

Edwards CB, Friedlander AM, Green AG, Hardt MJ and others (2014) Global assessment of the status of coral reef herbivorous fishes: evidence for fishing effects. Proc R Soc B 281:20131835

Fabricius KE (2005) Effects of terrestrial runoff on the ecology of corals and coral reefs: review and synthesis. Mar Pollut Bull 50:125-146

> Game ET, Bode M, McDonald-Madden E, Grantham HS, Possingham HP (2009) Dynamic marine protected areas can improve the resilience of coral reef systems. Ecol Lett 12:1336-1346

Gilmour JP, Smith LD, Heyward AJ, Baird AH, Pratchett MS (2013) Recovery of an isolated coral reef system following severe disturbance. Science 340:69-71

Golbuu Y, Victor S, Penland L, Idip D Jr and others (2007) Palau's coral reefs show differential habitat recovery following the 1998-bleaching event. Coral Reefs 26: 319-332

Gove JM, Williams GJ, McManus MA, Clark SJ, Ehses JS, Wedding LM (2015) Coral reef benthic regimes exhibit non-linear threshold responses to natural physical drivers. Mar Ecol Prog Ser 522:33-48

> Graham NAJ, Jennings S, MacNeil MA, Mouillot D, Wilson SK (2015) Predicting climate-driven regime shifts versus rebound potential in coral reefs. Nature 518:94-97

- Howell KL, Holt R, Endrino IP, Stewart H (2011) When the species is also a habitat: comparing the predictively mod- elled distributions of Lophelia pertusa and the reef habitat it forms. Biol Conserv 144:2656-2665

Hughes TP, Baird AH, Bellwood DR, Card M and others (2003) Climate change, human impacts, and the resilience of coral reefs. Science 301:929-933

Humphries AT, McClanahan TR, McQuaid CD (2014) Differential impacts of coral reef herbivores on algal succession in Kenya. Mar Ecol Prog Ser 504:119-132

> Johnson MD, Carpenter RC (2012) Ocean acidification and warming decrease calcification in the crustose coralline alga Hydrolithon onkodes and increase susceptibility to grazing. J Exp Mar Biol Ecol 434-435:94-101

Kennedy EV, Perry CT, Halloran PR, Iglesias-Prieto R and others (2013) Avoiding coral reef functional collapse requires local and global action. Curr Biol 23:912-918

Koweek D, Dunbar RB, Rogers JS, Williams GJ, Price N, Mucciarone D, Teneva L (2015) Environmental and ecological controls of coral community metabolism on Palmyra Atoll. Coral Reefs 34:339-351

Kroeker KJ, Kordas RL, Crim R, Hendriks IE and others (2013) Impacts of ocean acidification on marine organisms: quantifying sensitivities and interaction with warming. Glob Change Biol 19:1884-1896

Lewis SA (1986) The role of herbivorous fishes in the organization of a Caribbean reef community. Ecol Monogr 56: 183-200

> Lirman D, Fong P (2007) Is proximity to land-based sources of coral stressors an appropriate measure of risk to coral reefs? An example from the Florida Reef Tract. Mar Pollut Bull 54:779-791

Maina J, Venus V, McClanahan TR, Ateweberhan M (2008) Modelling susceptibility of coral reefs to environmental stress using remote sensing data and GIS models in the western Indian Ocean. Ecol Model 212:180-199

Maina J, McClanahan TR, Venus V, Ateweberhan M, Madin J (2011) Global gradients of coral exposure to environmental stresses and implications for local management. PLOS ONE 6:e23064

Mansfield ER, Helms BH (1982) Detecting multicollinearity. Am Stat 36:158-160

- Marshell A, Mumby PJ (2012) Revisiting the functional roles of the surgeonfish Acanthurus nigrofuscus and Ctenochaetus striatus. Coral Reefs 31:1093-1101

McClanahan TR (1994) Kenyan coral reef lagoon fish: effects of fishing, substrate complexity, and sea urchins. Coral Reefs 13:231-241

McClanahan TR (1999) Predation and the control of the sea urchin Echinometra viridis and fleshy algae in the patch reefs of Glovers Reef, Belize. Ecosystems 2:511-523

McClanahan TR (2000) Recovery of a coral reef keystone predator, Balistapus undulatus, in East African marine parks. Biol Conserv 94:191-198

McClanahan TR (2014) Recovery of functional groups and trophic relationships in tropical fisheries closures. Mar Ecol Prog Ser 497:13-23

> McClanahan TR, Humphries A (2012) Differential and slow life-history responses of fishes to coral reef closures. Mar Ecol Prog Ser 469:121-131

McClanahan TR, Karnauskas M (2011) Relationships between benthic cover, current strength, herbivory, and a fisheries closure in Glovers Reef Atoll, Belize. Coral Reefs 30:9-19

> McClanahan TR, Kaunda-Arara B (1996) Fishery recovery in a coral-reef marine park and its effect on the adjacent fishery. Conserv Biol 10:1187-1199 
McClanahan TR, Kurtis JD (1991) Population regulation of the rock-boring sea urchin Echinometra mathaei (de Blainville). J Exp Mar Biol Ecol 147:121-146

McClanahan TR, Maina J (2003) Response of coral assemblages to the interaction between natural temperature variation and rare warm-water events. Ecosystems 6: 551-563

> McClanahan TR, Muthiga NA (1989) Patterns of predation on a sea urchin, Echinometra mathaei (de Blainville), on Kenyan coral reefs. J Exp Mar Biol Ecol 126:77-94

McClanahan TR, Muthiga NA (2016) Geographic extent and variation of a coral reef trophic cascade. Ecology 97: 1862-1872

McClanahan T, Shafir SH (1990) Causes and consequences of sea urchin abundance and diversity in Kenyan coral reef lagoons. Oecologia 83:362-370

McClanahan TR, Muthiga NA, Kamukuru AT, Machano H, Kiambo RW (1999) The effects of marine parks and fishing on coral reefs of northern Tanzania. Biol Conserv 89: 161-182

McClanahan TR, Polunin NVC, Done T (2002) Ecological states and the resilience of coral reefs. Conserv Ecol 6:18

- McClanahan TR, Baker AC, Ateweberhan M, Maina J, Moothien-Pillay KR (2005) Refining coral bleaching experiments and models through reiterative field studies. Mar Ecol Prog Ser 305:301-303

> McClanahan TR, Ateweberhan M, Graham NAJ, Wilson SK, Sebastián CR, Guillaume MMM, Bruggemann JH (2007a) Western Indian Ocean coral communities: bleaching responses and susceptibility to extinction. Mar Ecol Prog Ser 337:1-13

McClanahan TR, Ateweberhan M, Muhando CA, Maina J, Mohammed SM (2007b) Effects of climate and seawater temperature variation on coral bleaching and mortality. Ecol Monogr 77:503-525

- McClanahan TR, Graham NAJ, Calnan JM, MacNeil MA (2007c) Toward pristine biomass: reef fish recovery in coral reef marine protected areas in Kenya. Ecol Appl 17: 1055-1067

> McClanahan TR, Maina JM, Muthiga NA (2011a) Associations between climate stress and coral reef diversity in the Western Indian Ocean. Glob Change Biol 17:2023-2032

> McClanahan TR, Muthiga NA, Coleman RA (2011b) Testing for top-down control: Can Caribbean algal phase shifts be reversed by post-disturbance fisheries closures? Aquat Conserv: Mar Freshw Ecosyst 21:658-675

McClanahan TR, Ateweberhan M, Darling ES, Graham NAJ, Muthiga NA (2014) Biogeography and change among regional coral communities across the Western Indian Ocean. PLOS ONE 9:e93385

- McClanahan TR, Maina J, Ateweberhan M (2015a) Regional coral responses to climate disturbances and warming is predicted by multivariate stress model and not temperature threshold metrics. Clim Change 131: 607-620

> McClanahan TR, Graham NAJ, MacNeil MA, Cinner JE (2015b) Biomass-based targets and the management of multispecies coral reef fisheries. Conserv Biol 29: 409-417

Mumby PJ (2016) Stratifying herbivore fisheries by habitat to avoid ecosystem overfishing of coral reefs. Fish Fish 17:266-278

> Mumby PJ, Dahlgren CP, Harborne AR, Kappel CV and others (2006) Fishing, trophic cascades, and the process of grazing on coral reefs. Science 311:98-101
Nash KL, Welsh JQ, Graham NAJ, Bellwood DR (2015) Home-range allometry in coral reef fishes: comparison to other vertebrates, methodological issues and management implications. Oecologia 177:73-83

- O'Leary JK, McClanahan TR (2010) Trophic cascades result in large-scale coralline algae loss through differential grazer effects. Ecology 91:3584-3597

O'Leary JK, Potts DC, Braga JC, McClanahan TR (2012) Indirect consequences of fishing: reduction of coralline algae suppresses juvenile coral abundance. Coral Reefs 31:547-559

- O'Leary JK, Potts D, Schoenrock KM, McClanahan TR (2013) Fish and sea urchin grazing opens settlement space equally but urchins reduce survival of coral recruits. Mar Ecol Prog Ser 493:165-177

Perry CT, Murphy GN, Graham NAJ, Wilson SK, Januchowski-Hartley FA, East HK (2015) Remote coral reefs can sustain high growth potential and may match future sea-level trends. Sci Rep 5:18289

> Qiu J, Lau DCC, Cheang C, Chow W (2014) Communitylevel destruction of hard corals by the sea urchin Diadema setosum. Mar Pollut Bull 85:783-788

> Rasher DB, Engel S, Bonito V, Fraser GJ, Montoya JP, Hay ME (2012) Effects of herbivory, nutrients, and reef protection on algal proliferation and coral growth on a tropical reef. Oecologia 169:187-198

> Russ GR, Questel SLA, Rizzari JR, Alcala AC (2015) The parrotfish-coral relationship: refuting the ubiquity of a prevailing paradigm. Mar Biol 162:2029-2045

$>$ Russo AR (1977) Water flow and the distribution and abundance of echinoids (genus Echinometra) on an Hawaiian Reef. Aust J Mar Freshw Res 28:693-702

Sall J, Lehmaan A, Creighton L (2001) JMP start statistics. Thomson Learning, Duxbury

Sammarco PW (1980) Diadema and its relationship to coral spat mortality: grazing, competition, and biological disturbance. J Exp Mar Biol Ecol 45:245-272

> Selig ER, Casey KS, Bruno JF (2012) Temperature-driven coral decline: the role of marine protected areas. Glob Change Biol 18:1561-1570

Shaw EC, Phinn SR, Tilbrook B, Steven A (2015) Natural in situ relationships suggest coral reef calcium carbonate production will decline with ocean acidification. Limnol Oceanogr 60:777-788

> Silverman J, Schneider K, Kline DI, Rivlin T and others (2014) Community calcification in Lizard Island, Great Barrier Reef: a 33 year perspective. Geochim Cosmochim Acta 144:72-81

Smith TB, Nemeth RS, Blondeau J, Calnan JM, Kadison E, Herzlieb S (2008) Assessing coral reef health across onshore to offshore stress gradients in the US Virgin Islands. Mar Pollut Bull 56:1983-1991

Smith JE, Hunter CL, Smith CM (2010) The effects of top-down versus bottom-up control on benthic coral reef community structure. Oecologia 163:497-507

Smith JE, Brainard R, Carter A, Grillo S and others (2016) Re-evaluating the health of coral reef communities: baselines and evidence for human impacts across the central Pacific. Proc R Soc B 283:20151985

Suchley A, McField MD, Alvarez-Filip L (2016) Rapidly increasing macroalgal cover not related to herbivorous fishes on Mesoamerican reefs. PeerJ 4:e2084

Sunday JM, Calosi P, Dupont S, Munday PL, Stillman JH, Reusch TBH (2014) Evolution in an acidifying ocean. Trends Ecol Evol 29:117-125 
Tanzil JTI, Brown BE, Tudhope AW (2009) Decline in skeletal growth of the coral Porites lutea from the Andaman Sea, South Thailand between 1984 and 2005. Coral Reefs 28:519-528

Tanzil JTI, Brown BE, Dunne RP, Lee JN, Kaandorp JA, Todd PA (2013) Regional decline in growth rates of massive Porites corals in Southeast Asia. Glob Change Biol 19:3011-3023

Thibaut LM, Connolly SR (2013) Understanding diversitystability relationships: towards a unified model of portfolio effects. Ecol Lett 16:140-150

Tuya F, Cisneros-Aguirre J, Ortega-Borges L, Haroun RJ (2007) Bathymetric segregation of sea urchins on reefs of the Canarian Archipelago: role of flow-induced forces.

Editorial responsibility: Ivan Nagelkerken, Adelaide, South Australia, Australia
Estuar Coast Shelf Sci 73:481-488

Vermeij GJ (1987) Evolution and escalation: an ecological history of life. Princeton University Press, Princeton, NJ

Warton DI, Hui FKC (2011) The arcsine is asinine: the analysis of proportions in ecology. Ecology 92:3-10

Wild C, Hoegh-Guldberg O, Naumann MS, Colombo-Pallotta MF and others (2011) Climate change impedes scleractinian corals as primary reef ecosystem engineers. Mar Freshw Res 62:205-215

Wilson SK, Graham NAJ, Fisher R, Robinson J and others (2012) Effect of macroalgal expansion and Marine Protected Areas on coral recovery following a climatic disturbance. Conserv Biol 26:995-1004

Submitted: May 18, 2016; Accepted: September 30, 2016 Proofs received from author(s): November 15, 2016 